
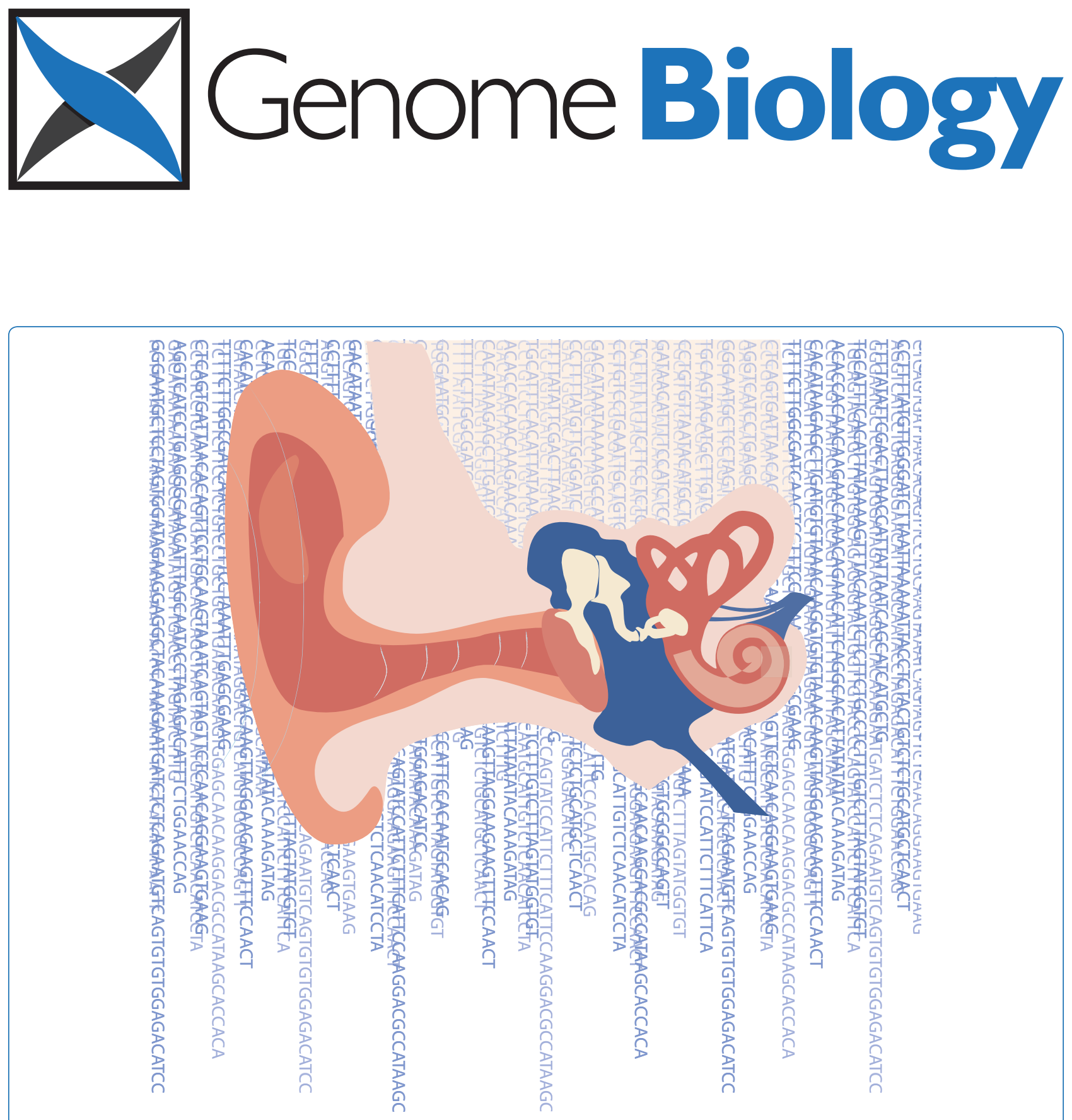

\title{
High-throughput sequencing to decipher the genetic heterogeneity of deafness
}

Zippora Brownstein, Yoni Bhonker and Karen B Avraham 


\section{High-throughput sequencing to decipher the genetic heterogeneity of deafness}

Zippora Brownstein, Yoni Bhonker and Karen B Avraham*

\begin{abstract}
Identifying genes causing non-syndromic hearing loss has been challenging using traditional approaches. We describe the impact that high-throughput sequencing approaches are having in discovery of genes related to hearing loss and the implications for clinical diagnosis.

Keywords Genomics, deep sequencing, massive parallel sequencing, next-generation sequencing, exome sequencing, homozygosity mapping, hearing loss
\end{abstract}

\section{Introduction}

The identification of genes responsible for medically important traits is a major challenge in human genetics. This is particularly so for a disease with heterogenic pathology, such as hearing loss (HL). Hearing impairment is the most common sensory defect, affecting approximately one in 500 newborns and $4 \%$ of people younger than 45 years [1], reaching $50 \%$ by age 80 [2]. It is estimated that 278 million people worldwide suffer from $\mathrm{HL}$ $[3,4]$, affecting child development, education, social integration, and the quality of life of the affected individual, with a substantial impact on public health. This high prevalence, combined with the striking genetic heterogeneity of deafness, has made this Mendelian disease a major challenge in terms of discovering its cause and deciphering the mechanisms underlying it. Sixty-three genes encoding proteins with a broad range of functions are known to be involved in HL. Many more are expected to be discovered, as over 100 loci have been mapped without the corresponding gene identified. However, because of the technological limitations in clinical diagnostics, mainly resulting from the large size of many genes and the high cost of Sanger sequencing, many

*Correspondence: karena@post.tau.ac.il

Department of Human Molecular Genetics and Biochemistry, Sackler Faculty of Medicine, Tel Aviv University, Tel Aviv 69978, Israel hearing-impaired individuals with familial HL do not know the genetic cause of their HL. Owing to the complexity of the auditory apparatus and the vast genetic heterogeneity of HL, high-throughput sequencing, also known as massively parallel sequencing or next-generation sequencing (NGS), is the ideal tool to address this challenge (Box 1).

NGS has already had an important impact on both research and clinical diagnosis in other diseases, such as breast cancer [5], intractable inflammatory bowel disease [6] and Kabuki syndrome [7], as it enables screening of a large number of genes in one test. In addition, this approach does not require the collection of DNA samples from large affected families that previous linkage-based approaches to disease gene identification did. The recent advances in molecular biology and genomics have raised hopes of elucidating the complex network of auditory genes, which is the first step toward implementing a cure for HL. These advances highlight the need for additional discovery and characterization of all genes involved in HL. Here, we focus on the impact of genomics, and in particular NGS, on the progress in gene discovery for inherited deafness.

\section{Unraveling the genetic complexity of HL by high-throughput strategies}

At least $60 \%$ of $\mathrm{HL}$ is regarded as having a genetic cause, as many of the environmental causes, such as ototoxic drugs, mumps or rubella, have been eliminated by modern medicine. Most environmental causes, including exposure to ototoxic drugs, exposure to rubella during gestation, trauma and excessive noise, are considered to have a genetic basis as well, as both the onset and severity of acquired hearing impairment may depend on the genetic background of the individual. Approximately $70 \%$ of all genetic HL is non-syndromic (NSHL), with half predicted to be monogenic. NSHL is inherited in a recessive mode in approximately $80 \%$ of cases, in a dominant mode in approximately $20 \%$, and is either Xlinked or mitochondrial in origin in 2 to $3 \%$.

Mutations in over 60 genes have been found to disrupt auditory function, resulting in similar or different phenotypes, according to the function, location, pathway 


\begin{abstract}
Box 1
The development of Sanger sequencing in 1977 [55] marked a turning point in the molecular genetics revolution, and this was followed by the implementation of the polymerase chain reaction 6 years later [56]. These landmarks paved the way for the Human Genome Project, completed in 2001 [57]. The field of genomics and its technological capacity have evolved at an extremely rapid pace since, leading to the development of highthroughput methods, including next-generation sequencing (NGS), also called massively parallel sequencing or deep sequencing. These advanced technologies, besides enhancing the ability to identify human disease mutations, have yielded a flood of genomic data. The increased wealth of genomic information has accelerated our understanding of complex biological processes and has provided broad clinical implications, but it has also required the development of advanced bioinformatics tools to deal with these massive amounts of data. NGS can produce over 10,000 times more data than the Sanger sequencing method. Whereas Sanger sequencing yields a 24-hour output of 120,000 bp for the cost of $\$ 4,000$ per Mb sequenced [23], the output of a single NGS machine is larger than $30 \mathrm{~Gb}$ in 24 hours and costs less than $\$ 2$ per Mb. The $3.2 \mathrm{~Gb}$ in a single human genome can therefore be sequenced in 1 day at a fairly low cost relative to what it would take with Sanger sequencing - up to 73 years at a cost of $\$ 200,000$ [58]. We are rapidly reaching the long-held dream of the $\$ 1,000$ genome in less than a day, although the subsequent bioinformatic analysis is becoming the new bottleneck for rapid genome-based diagnosis.
\end{abstract}

or network of proteins they encode [8]. These genes encode a variety of proteins with a broad range of functions, including gap junctions (connexin 26 and connexin 32), transcription factors (POU4F3, POU3F4, TFCP2L3 and PAX3), ion channels (KCNQ1, KCNE1 and KCNQ4), molecular motors (myosin VI, myosin VIIA, SLC26A4 and prestin), extracellular proteins (alpha-tectorin, otoancorin and COL11A2) and structural proteins (otoferlin and diaphanous 1). Their expression pattern varies between proteins that are exclusively expressed in the mammalian inner ear ( $\alpha$-tectorin, cochlin and EYA4), to proteins that are expressed in several tissues (myosin VI, POU4F3 and whirlin), but surprisingly have mostly only been found to be involved in HL (reviewed in [9]). The many proteins required for proper functioning of the inner ear correlate with the complex structure of its six organs: the cochlea, responsible for hearing, and the saccule, utricle and the three semicircular canals, which control balance and spatial orientation. The development, differentiation and maintenance of this complex machinery explain the involvement of such a large number of genes with mutations leading to HL. Distinct proteins are responsible for the function of each compartment of the inner ear, as well as for the physiological and mechanistic aspects.
The ear itself is divided into three compartments: the outer, the middle and the inner ear (Figure 1; reviewed in [10]). The inner ear includes both the organ of hearing (cochlea) and the vestibular sense organs. The cochlea is a coiled snail-shaped organ in the temporal bone. The organ of Corti, containing hair cells and supporting cells, lies on the basilar membrane that separates the scala media from scala tympani. When sound strikes the tympanic membrane, the movement transferred by the footplate of the stapes presses it into the cochlear duct through the oval window, causing the fluids to move through the cochlear duct, flowing against the receptor cells (hair cells) of the organ of Corti. The hair cells in the organ of Corti are composed of an inner row and three outer rows of hair cells. The apical side of the hair cells facing the scala media contains the stereocilia, actin-rich projections with a typical staircase arrangement, connected with lateral and tip links. On top of the hair cells lies the tectorial membrane, a collagen-rich extracellular matrix. The vibrations caused by sound activate mechanoelectrical transduction by triggering the hair cells via deflection of the hair bundles and enabling potassium influx through the apical transduction channels that depolarizes the cells. A multitude of proteins are involved in every step of the hearing process, and a mutation in any one of the genes that encode these proteins can have dire consequences on hearing.

The gene most frequently involved in $\mathrm{HL}$ is GJB2, encoding the connexin 26 protein, with more than 100 dominant or recessive deafness-causing mutations detected in this small gene of only one coding exon of approximately $1 \mathrm{~kb}$. Other frequently mutated genes include SLC26A4, MYO15A, OTOF, CDH23 and TMC1, with over 20 mutations reported to be involved in HL for each of these genes. A comprehensive list of genes implicated in $\mathrm{HL}$ can be found at the deafness variation database [11]. The number of mutations in the other 'deafness' genes is lower and most of them have been reported in consanguineous families [12]. However, unlike GJB2, many of these genes are large, with dozens of exons, such as MYO15A and CDH23, which have 65 and 68 exons, respectively. The number of genes and mutations found are most likely underestimated as a result of the pre-NGS era strategies used for gene identification. For example, large genes are not routinely completely analyzed using Sanger sequencing, as it is too time- and cost-consuming to be performed as part of routine clinical genetic diagnosis. Even for research purposes, the number of large genes involved in HL has made complete sequencing on a regular basis impractical, unless there were strong reasons to expect a mutation because of shared ethnic origin or phenotype. For the same practical reasons, the methods used for detection of known mutations (mutation-specific assays) have also led to an 


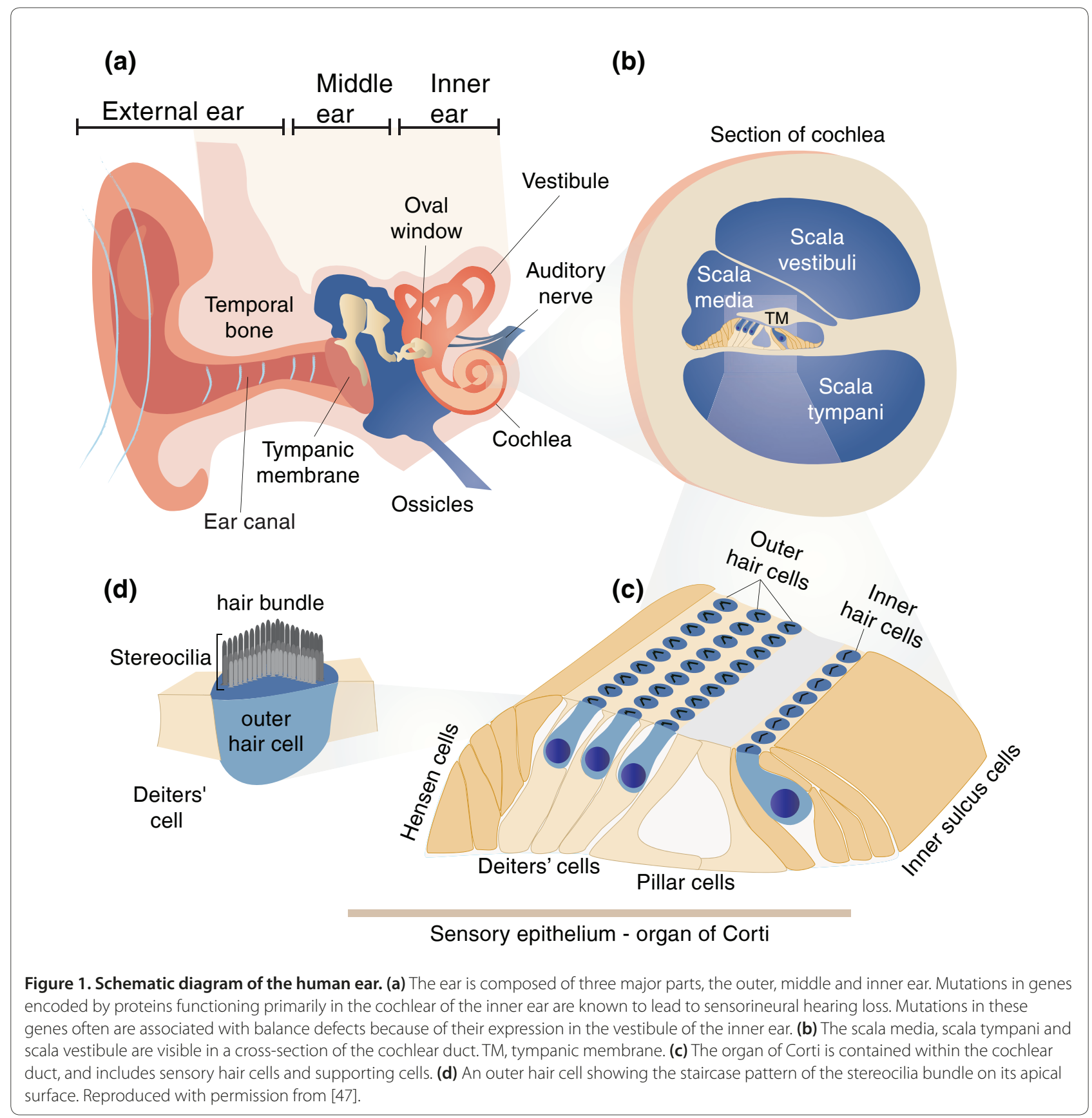

underestimation of the numbers of mutations in prevalent deafness genes, such as GJB2 and $S L C 26 A 4$. In addition, some genes have been found to be associated with deafness in a particular population or one family, discouraging others from searching for mutations in these genes (if mutations in a particular gene were only found infrequently, scientists were less inclined to want to screen for mutations in this gene).

Although families with HL with different modes of inheritance are found all over the world, the majority of families reported with recessive deafness come from countries where consanguineous families are common, including North Africa, through the Middle East to India and Pakistan. The deafness loci for these consanguineous families were easily mapped by linkage analysis and homozygosity mapping, allowing locus identification using only a large single family. Dominant $\mathrm{HL}$, in contrast, was mainly identified in families originating in Europe, North America and Australia [12].

Before the high-throughput technology era, disease locus identification was performed mainly by genomewide linkage analysis using genetic markers, such as 
microsatellites or single nucleotide polymorphisms, commonly known as SNPs. The genetic linkage data obtained could be analyzed by various methods, such as parametric multipoint linkage analysis and, when relevant, homozygosity mapping, used to detect disease loci for autosomal recessive disorders, particularly in consanguineous pedigrees [13]. Even though this approach led to the identification of many deafness genes, particularly in populations with social preference for endogamous or consanguineous marriage and large family size [14], it has significant limitations, including that it is suitable only for families with recessive diseases and needs at least two affected offspring, preferably with related parents. The limitations of linkage methods, the long time required and high cost of gene identification left many cases unsolved and the list of unresolved human loci linked with HL remained longer than the list of cloned genes [8]. However, the linkage methods identified only one gene in each experiment and thus, in many of these cases, mutations were found in only one family, and in many other cases the causative gene has remained unknown.

To overcome this obstacle, efforts for large-scale screening of deafness genes have emerged, for example, by genotyping 198 mutations with a primer extension across eight prevalent genes (GJB2, GJB6, GJB3, GJA1, SLC26A4, SLC26A5, MTRNR1 and MTTS1) in a single test [15]. Chromosomal imbalances have been identified by array comparative genomic hybridization (array CGH). For example, an inverted genomic duplication of the TJP2 gene was identified as the cause of progressive NSHL at the DFNA51 locus using this method [16]. However, this technique can detect only large deletions or duplications, and was used after failing to detect standard mutations by other methods. Moreover, a systematic study of unsolved deafness cases has not been undertaken using array CGH, so it is not known what proportion of deafness is caused by large duplications or deletions. Clearly, there has been a need to develop techniques for largescale screening of a larger number of genes in a reasonable amount of time and more cost-effective manner that can detect all types of mutations underlying deafness.

An example demonstrating the underestimated numbers of deafness genes in a given population is found in the Jewish Israeli population before the NGS era. In this population, the number of NSHL genes was estimated to be up to 22 across the Jewish ethnic groups [17]. Before using high-throughput methods, nine NSHL genes were found over a period of 15 years [18]. This number dramatically increased to 14 , in a single experiment of targeted genomic capture followed by NGS, conducted on only five unrelated deaf individuals [19], promising a much larger number if all unsolved deaf probands were to be enrolled in this type of experiment.

\section{Deep sequencing for hearing loss - a milestone on the road to unraveling the auditory complex}

Three commercial NGS technologies have been developed in recent years, each with its own advantages and disadvantages. These include pyrosequencing with the 454 sequencer (Roche Life Sciences) [20], cyclic reversible termination technology using the Illumina platform (Illumina) [21], and sequence-by-ligation technology using the SOLiD platform (Applied Biosystems) [22] (for a comprehensive review, see $[23,24]$ ). These platforms have addressed the main problem of detecting causative mutations for heterogenic diseases, including those with dozens of genes involved, as is the case for deafness. Two of these platforms were compared in a targeted genomic capture and NGS experiment, in an effort to determine the most efficient method for identifying deafness genes for screening towards clinical diagnosis [25]. Although both the SureSelect-Illumina and NimbleGen-454 platforms provided high specificity and sensitivity, the authors [25] concluded that the former platform was preferable with regard to scale, sensitivity and cost under their conditions. This combined approach, targeted capture and sequencing, seems to be the ideal tool to address the challenges of deciphering the genetics underlying HL: it enables the detection of all types of mutations; it allows the screening of large genes that have previously been largely untested; it can include all known deafness genes in a single test; and it can be used in cases of isolated deafness.

Several studies have used a combination of targeted capture and NGS technology to identify deafness genes. The first study was used to isolate the HL-associated gene at the DFNB79 locus [26]. Targeted genomic capture was performed on the linked region identified previously by genetic analysis, leading to the identification of a mutation in the TPRN gene, encoding taperin. Subsequent capture and NGS experiments for both non-syndromic and syndromic HL were undertaken and are listed in Table 1. Both specific genomic regions and whole exomes were captured, leading to the successful identification of the molecular basis of several forms of HL. The comparative NGS study described above also developed OtoSCOPE, a platform for providing a clinical test for 57 known deafness genes [25]. Another clinical assay, testing 84 human genes involved in both syndromic HL and NSHL, is also available from Otogenetics (reviewed in [27]).

In a further effort to develop clinical diagnosis platforms for identifying multiple mutations, a combined targeted genomic capture and NGS of 246 genes was conducted on a cohort of Middle Eastern hearing-impaired probands [19]. In this study, screening additional families for alleles first identified by NGS in five probands led to the identification of causative alleles for deafness in 
Table 1. The contribution of targeted capture and next-generation sequencing to hearing research

\begin{tabular}{|c|c|c|c|c|c|}
\hline $\begin{array}{l}\text { Locus and } \\
\text { inheritance }\end{array}$ & $\begin{array}{l}\text { Individuals } \\
\text { sequenced }\end{array}$ & $\begin{array}{l}\text { Targeted } \\
\text { regions }\end{array}$ & $\begin{array}{l}\text { Whole exome } \\
\text { region analyzed } \\
\text { by bioinformatics }\end{array}$ & $\begin{array}{l}\text { Novel } \\
\text { discoveries }\end{array}$ & Reference \\
\hline DFNB79 & One & $2.9 \mathrm{Mb}$, chromosome 9q34.3 & & TPRN & Rehman et al. [26] \\
\hline DFNB82 & One & Whole exome & $3.1 \mathrm{Mb}, 1 \mathrm{p} 13.3$ & GPSM2 & Walsh et al. [29] \\
\hline $\begin{array}{l}\text { Syndromic } \\
\text { (Perrault syndrome) }\end{array}$ & One & Whole exome & & HSD17B4/DBP & Pierce et al. [40] \\
\hline $\begin{array}{l}\text { Syndromic } \\
\text { (3MC) }\end{array}$ & One & Whole exome & $1.81 \mathrm{Mb}, 3 \mathrm{q} 27$ & MASP1 & Sirmaci et al. [41] \\
\hline $\begin{array}{l}\text { Dominant and } \\
\text { recessive NSHL }\end{array}$ & Nine & $\begin{array}{l}54 \text { known deafness genes, } \\
\text { exons }\end{array}$ & & $\begin{array}{l}\text { Three novel mutations in } \\
\text { known deafness genes }\end{array}$ & Shearer et al. [25] \\
\hline DFNA4 & One & Whole exome & $20 \mathrm{Mb}, 19 \mathrm{q} 12-13.4$ & CEACAM16 & Zheng et al. [42] \\
\hline $\begin{array}{l}\text { Syndromic } \\
\text { (Perrault syndrome) }\end{array}$ & One & $\begin{array}{l}\text { 4.142-Mb linkage region, } \\
\text { chromosome } 5 \mathrm{q} 31\end{array}$ & & HARS2 & Pierce et al. [43] \\
\hline DFNX4 & One & X chromosome & $12.9 \mathrm{Mb}$, Xp22 & SMPX & Schraders et al. [31] \\
\hline DFNX4 & Two brothers & $\begin{array}{l}88 \text { genes, exons, } 1 \text { kb promoter } \\
\text { regions, } 17.5 \mathrm{Mb} \text { region, } \\
\text { chromosome Xp22.12 }\end{array}$ & $17.5 \mathrm{Mb}, \mathrm{Xp} 22.12$ & SMPX & Huebner et al. [32] \\
\hline $\begin{array}{l}\text { Syndromic } \\
\text { (HSAN1) }\end{array}$ & One & Whole exome & $3.4 \mathrm{Mb}, 19 \mathrm{p} 13.2$ & DNMT1 & Klein et al. [44] \\
\hline $\begin{array}{l}\text { Dominant and } \\
\text { recessive NSHL }\end{array}$ & 11 unrelated & $\begin{array}{l}246 \text { genes responsible for } \\
\text { deafness in humans and mice, } \\
\text { exons and } 40 \text { bp flanking introns }\end{array}$ & & $\begin{array}{l}\text { Four novel mutations in } \\
\text { known deafness genes }\end{array}$ & Brownstein et al. [19] \\
\hline $\begin{array}{l}\text { Mitochondrial } \\
\text { (OXPHOS disease) }\end{array}$ & One & $\begin{array}{l}1,034 \text { nuclear genes encoding } \\
\text { mitochondrial proteins, entire } \\
\text { mtDNA and exons }\end{array}$ & & None & Calvo et al. [45] \\
\hline Recessive NSHL & One & Whole exome & $\begin{array}{l}36.9 \mathrm{Mb} \text {, chromosomes } \\
8,15,16,19,21\end{array}$ & $\begin{array}{l}\text { Mutation in known } \\
\text { deafness gene }\end{array}$ & Sirmaci et al. [30] \\
\hline $\begin{array}{l}\text { Syndromic } \\
\text { (ADCA-DN) }\end{array}$ & Five & Whole exome & & $\begin{array}{l}\text { Mutation in known } \\
\text { deafness gene }\end{array}$ & Winkelmann et al. [46] \\
\hline
\end{tabular}

25 families. In addition, orthologs of mouse deafness genes were included on the platform, based on the premise that mutations in these genes may lead to human $\mathrm{HL}$, because many of the human HL genes also cause HL in mice. This approach exploits the high-throughput nature of targeted NGS to make a single fully comprehensive test for all known deafness genes and has the advantage of producing a significantly reduced amount of data compared with exome sequencing or whole genome sequencing. Nevertheless, the data obtained from sequencing of the exons of approximately 250 genes, with an additional 40 nucleotides on each end into the introns, required extensive bioinformatics analysis and filtering out of thousands of non-damaging variants. A schematic diagram of the strategy for generating such an experimental and computational pipeline can be seen in Figure 2. A summary of the strategy used for data analysis and for eliminating all irrelevant variants by evaluation of putative causative mutations for validation is shown in Figure 3.

On a larger scale, whole exome sequencing is extremely promising, as it screens the exons of all genes in the human genome, enabling the discovery of novel deafness genes. It is estimated that approximately $60 \%$ of genes for Mendelian disease could be discovered using this technology [28]. The data analysis is rather complicated and strategies are being used to ease this. One conducts homozygosity mapping for recessive families to narrow down the regions to analyze. This was done, in parallel to exome sequencing, leading to the identification of a GPSM2 mutation as the cause of HL associated with the DFNB82 locus [29] and a GIPC3 mutation in a family with consanguineous parents [30].

In addition to clinical diagnostics, a major goal of gene discovery is to decipher the mechanisms involved in deafness. Exome sequencing, through the initial findings 


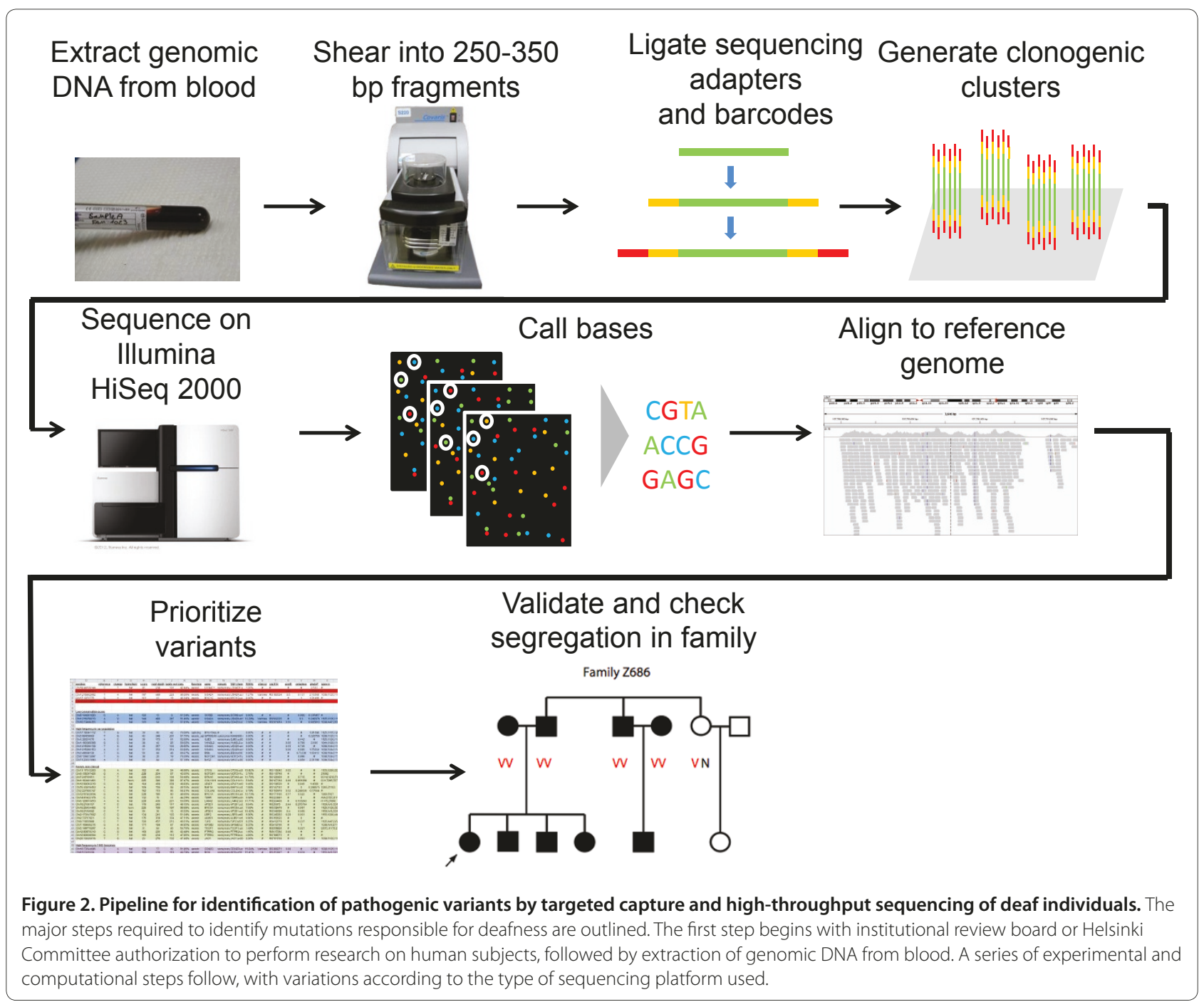

of new genes associated with deafness, has provided this entry point for new biological insights. For example, although exome sequencing indicated that SMPX is the most suitable candidate for progressive hearing impairment in a large Dutch family, it did not seem to be an obvious candidate from a biological perspective, because the protein encoded by this gene had been implicated in striated muscle [31,32]. Further investigations revealed that SMPX is indeed expressed in the cochlea and a role in development and/or maintenance of the sensory hair cells through integrin signaling and/or the insulin-like growth factor-1 pathway has been suggested. Thus, the next-generation sequencing approach has implicated new genes and pathways in deafness.

\section{Conclusion}

There are several remaining questions with regard to deep sequencing for hereditary HL. Will this technique become routine for HL? Will it be adopted by clinical laboratories on a routine basis? What are the ethical considerations involved? Much of the effort invested in the field of genomics aims to improve medical strategies in diagnostics, treatment, cure and prevention of disabilities. Although most disabled people welcome the new technologies, others might be ambivalent or even antagonistic towards genetic medicine [33]. For deafness in particular, there has been an ongoing debate whether deafness is a real disability or rather a different culture [34]. Although some communities, particularly in religious communities in the Middle East, consider deafness to be an unwanted disability, at the other extreme, there are deaf parents who would prefer to have deaf children and are ready to go as far as terminating a pregnancy if the fetus does not have HL [35]. Even though the majority of deaf couples are not interested in prenatal diagnosis for $\mathrm{HL}$, and tend to feel that termination of pregnancy on the basis of hearing status (either deaf or hearing) should be illegal [36], many hearing parents, after the birth of a deaf 


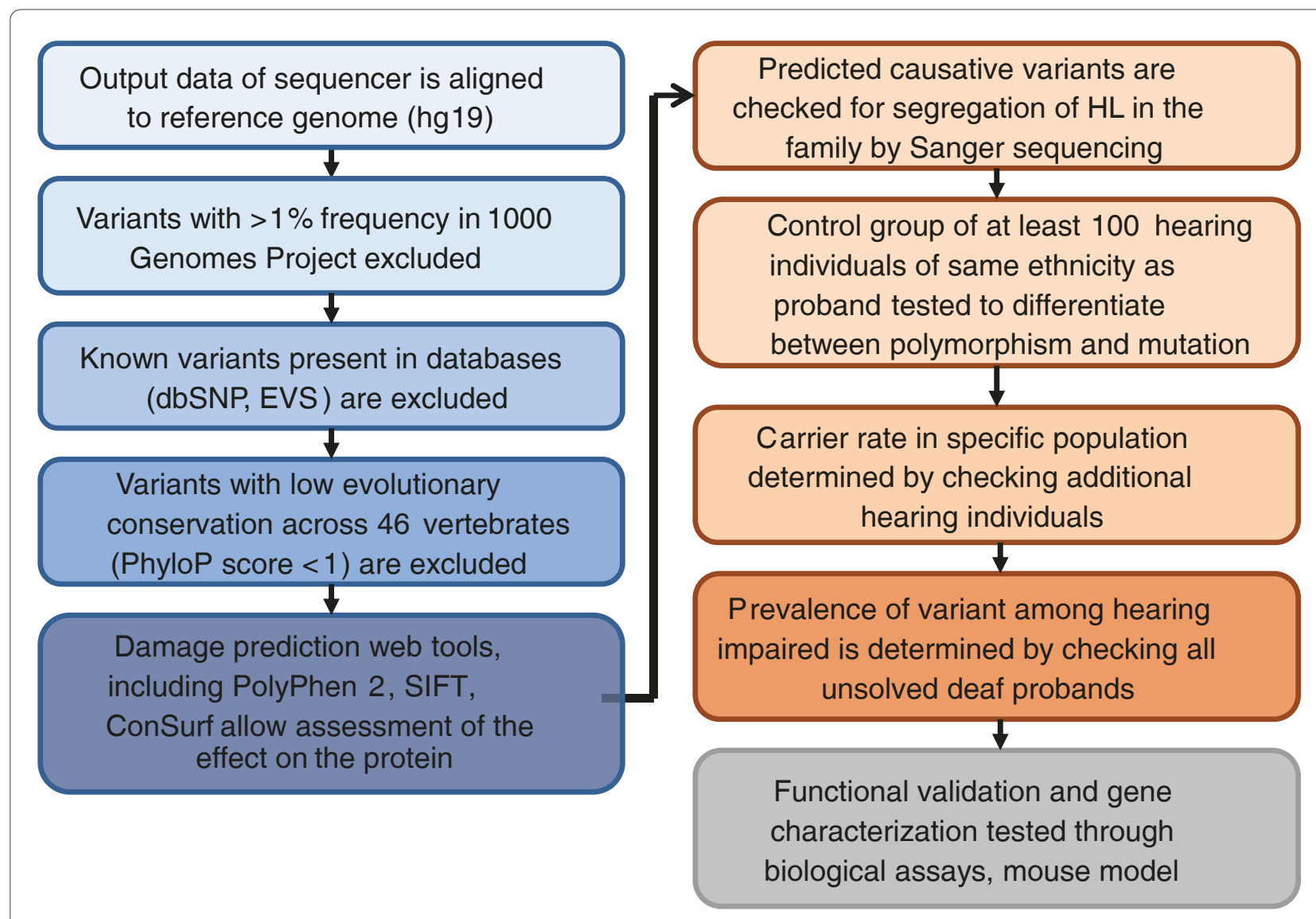

Figure 3. Prioritization of variants to identify causative hearing loss mutations. A series of computational steps (blue background) are required to tackle the many variants that come out of the high-throughput sequencing. High-confidence candidates will be further tested (orange background) in the proband's family and ethnic group using Sanger sequencing or restriction enzyme assays. Confirmed pathogenic mutations will be tested for biological function (gray background). Websites of the tools shown are at: 1000 Genomes Project [48]; dbSNP [49]; EVS [50]; PhyloP [51]; PolyPhen2 [52]; SIFT [53]; ConSurf [54].

child, seek genetic counseling to prevent the reoccurrence of deafness in their family and some of them would consider termination of a hearing-impaired child [37].

From a wider point of view, HL has serious consequences for public health, with major economic and social implications, as it is estimated that at least $20 \%$ of the population develop a significant $\mathrm{HL}$ at some time during their lives [36]. Because of the high heterogeneity of deafness, most deaf people are born to hearing parents, and most of this population has a strong desire for treatment or cure. Therefore, a major challenge is to discover the cause and decipher the mechanisms of deafness. Recent advances in genomics have made it possible to perform large-scale population screening, as well as for individualized testing. However, high-throughput genomics in the clinical setting is still in its infancy and before implementing it in routine clinical use, there is a clear need for standard laboratory procedures and regulations for quality control, data analysis and validation [38]. Efforts in this direction have been initiated by the
Centers for Disease Control and Prevention that sponsored a conference in 2011 on Next-Generation Sequencing, Standardization of Clinical Testing [27]. In addition, there are controversial ethical issues regarding the immense amount of high-throughput data obtained and their applications, because these data are usually much broader than the specific topic of research. Precise rules for the use, storage and sharing of NGS data among collaborative research groups are currently lacking. In many cases data are required to be deposited in publicly accessible databases by research funding sources before publication [39]. All these make informed consent for genomics difficult to define.

Nevertheless, initial findings of these advanced technologies for detection of deafness-causing mutations promise to solve the major portion of genetic deafness in the next few years, which will lead to improved genetic counseling and much more efficient treatment, as phenotypes could be predicted by the solved genotypes. Characterization of the proteins encoded by these genes 
will shed light on the biological mechanisms involved in the pathophysiology of HL, forming the basis for geneticbased therapeutics.

\section{Acknowledgements}

Research in the Avraham laboratory for human genomics research is funded by the National Institutes of Health (NIDCD) R01DC011835, I-CORE Center No 41/11, and the Hedrich Charitable Trust.

Published: 29 May 2012

\section{References}

1. Estivill X, Fortina P, Surrey S, Rabionet R, Melchionda S, D'Agruma L, Mansfield E, Rappaport E, Govea N, Mila M, Zelante L, Gasparini P: Connexin-26 mutations in sporadic and inherited sensorineural deafness. Lancet 1998, 351:394-398.

2. Nadol JB Jr: Hearing loss. N Engl J Med 1993, 329:1092-1102.

3. Morton CC, Nance WE: Newborn hearing screening-a silent revolution. N Engl J Med 2006, 354:2151-2164.

4. Smith RJ, Bale JF Jr, White KR: Sensorineural hearing loss in children. Lance 2005, 365:879-890

5. Walsh T, Lee MK, Casadei S, Thornton AM, Stray SM, Pennil C, Nord AS, Mandell JB, Swisher EM, King MC: Detection of inherited mutations for breast and ovarian cancer using genomic capture and massively parallel sequencing. Proc Natl Acad SciU S A 2010, 107:12629-12633.

6. Worthey EA, Mayer AN, Syverson GD, Helbling D, Bonacci BB, Decker B, Serpe JM, Dasu T, Tschannen MR, Veith RL, Basehore MJ, Broeckel U, Tomita-Mitchell A, Arca MJ, Casper JT, Margolis DA, Bick DP, Hessner MJ, Routes JM, Verbsky JW, Jacob HJ, Dimmock DP: Making a definitive diagnosis: successful clinical application of whole exome sequencing in a child with intractable inflammatory bowel disease. Genet Med 2011, 13:255-262.

7. Ng SB, Bigham AW, Buckingham KJ, Hannibal MC, MCMillin MJ, Gildersleeve HI, Beck AE, Tabor HK, Cooper GM, Mefford HC, Lee C, Turner EH, Smith JD, Rieder MJ, Yoshiura K, Matsumoto N, Ohta T, Niikawa N, Nickerson DA, Bamshad MJ, Shendure J: Exome sequencing identifies MLL2 mutations as a cause of Kabuki syndrome. Nat Genet 2010, 42:790-793.

8. Hereditary Hearing loss Homepage [http://hereditaryhearingloss.org/]

9. Richardson GP, de Monvel JB, Petit C: How the genetics of deafness illuminates auditory physiology. Annu Rev Physiol 2011, 73:311-334.

10. Dror AA, Avraham KB: Hearing loss: mechanisms revealed by genetics and cell biology. Annu Rev Genet 2009, 43:411-437.

11. Deafness Variation Database [http://deafnessvariationdatabase.com/]

12. Hilgert N, Smith RJ, Van Camp G: Forty-six genes causing nonsyndromic hearing impairment: which ones should be analyzed in DNA diagnostics? Mutat Res 2009, 681:189-196.

13. Lander ES, Botstein D: Homozygosity mapping: a way to map human recessive traits with the DNA of inbred children. Science 1987, 236:1567-1570

14. Christianson A, Modell B: Medical genetics in developing countries. Annu Rev Genomics Hum Genet 2004, 5:219-265.

15. Rodriguez-Paris J, Pique L, Colen T, Roberson J, Gardner P, Schrijver I: Genotyping with a 198 mutation arrayed primer extension array for hereditary hearing loss: assessment of its diagnostic value for medical practice. PLoS One 2010, 5:e11804

16. Walsh T, Pierce SB, Lenz DR, Brownstein Z, Dagan-Rosenfeld O, Shahin H, Roeb W, McCarthy S, Nord AS, Gordon CR, Ben-Neriah Z, Sebat J, Kanaan M, Lee MK, Frydman M, King MC, Avraham KB: Genomic duplication and overexpression of TJP2/ZO-2 leads to altered expression of apoptosis genes in progressive nonsyndromic hearing loss DFNA51. Am J Hum Genet 2010, 87:101-109.

17. Brownstein Z, Friedlander Y, Peritz E, Cohen T: Estimated number of loci for autosomal recessive severe nerve deafness within the Israeli Jewish population, with implications for genetic counseling. Am J Med Genet 1991, 41:306-312

18. Brownstein Z, Avraham KB: Deafness genes in Israel: implications for diagnostics in the clinic. Pediatr Res 2009, 66:128-134.

19. Brownstein Z, Friedman LM, Shahin H, Oron-Karni V, Kol N, Rayyan AA, Parzefall T, Lev D, Shalev S, Frydman M, Davidov B, Shohat M, Rahile M, Lieberman S, Levy-Lahad E, Lee MK, Shomron N, King MC, Walsh T, Kanaan M, Avraham KB: Targeted genomic capture and massively parallel sequencing to identify genes for hereditary hearing loss in middle eastern families. Genome Biol 2011, 12:R89.

20. Margulies M, Egholm M, Altman WE, Attiya S, Bader JS, Bemben LA, Berka J, Braverman MS, Chen YJ, Chen Z, Dewell SB, Du L, Fierro JM, Gomes XV, Godwin BC, He W, Helgesen S, Ho CH, Irzyk GP, Jando SC, Alenquer ML, Jarvie $T P$, Jirage KB, Kim JB, Knight JR, Lanza JR, Leamon JH, Lefkowitz SM, Lei M, Li J, et al: Genome sequencing in microfabricated high-density picolitre reactors. Nature 2005, 437:376-380.

21. Ju J, Kim DH, Bi L, Meng Q, Bai X, Li Z, Li X, Marma MS, Shi S, Wu J, Edwards JR, Romu A, Turro NJ: Four-color DNA sequencing by synthesis using cleavable fluorescent nucleotide reversible terminators. Proc Natl Acad Sci U S A 2006, 103:19635-19640.

22. Valouev A, Ichikawa J, Tonthat T, Stuart J, Ranade S, Peckham H, Zeng K, Malek JA, Costa G, McKernan K, Sidow A, Fire A, Johnson SM: A high-resolution, nucleosome position map of $C$. elegans reveals a lack of universal sequence-dictated positioning. Genome Res 2008, 18:1051-1063.

23. Metzker ML: Sequencing technologies - the next generation. Nat Rev Genet 2010, 11:31-46

24. Shearer AE, Hildebrand MS, Sloan CM, Smith RJ: Deafness in the genomics era. Hear Res 2011, 282:1-9.

25. Shearer AE, DeLuca AP, Hildebrand MS, Taylor KR, Gurrola J, 2nd, Scherer S, Scheetz TE, Smith RJ: Comprehensive genetic testing for hereditary hearing loss using massively parallel sequencing. Proc Natl Acad Sci U S A 2010, 107:21104-21109.

26. Rehman AU, Morell RJ, Belyantseva IA, Khan SY, Boger ET, Shahzad M, Ahmed ZM, Riazuddin S, Khan SN, Friedman TB: Targeted capture and nextgeneration sequencing identifies C9orf75, encoding taperin, as the mutated gene in nonsyndromic deafness DFNB79. Am J Hum Genet 2010, 86:378-388.

27. Lin X, Tang W, Ahmad S, Lu J, Colby CC, Zhu J, Yu Q: Applications of targeted gene capture and next-generation sequencing technologies in studies of human deafness and other genetic disabilities. Hear Res 2012, doi:10.1016/ j.heares.2012.01.004.

28. Gilissen C, Hoischen A, Brunner HG, Veltman JA: Disease gene identification strategies for exome sequencing. Eur J Hum Genet 2012, 20:490-497.

29. Walsh T, Shahin H, Elkan-Miller T, Lee MK, Thornton AM, Roeb W, Abu Rayyan A, Loulus S, Avraham KB, King MC, Kanaan M: Whole exome sequencing and homozygosity mapping identify mutation in the cell polarity protein GPSM2 as the cause of nonsyndromic hearing loss DFNB82. Am J Hum Genet 2010, 87:90-94.

30. Sirmaci A, Edwards YJ, Akay H, Tekin M: Challenges in whole exome sequencing: an example from hereditary deafness. PLoS One 2012 7:e32000.

31. Schraders M, Haas SA, Weegerink NJ, Oostrik J, Hu H, Hoefsloot LH, Kannan S, Huygen PL, Pennings RJ, Admiraal RJ, Kalscheuer VM, Kunst HP, Kremer H: Next-generation sequencing identifies mutations of SMPX, which encodes the small muscle protein, $X$-linked, as a cause of progressive hearing impairment. Am J Hum Genet 2011, 88:628-634.

32. Huebner AK, Gandia M, Frommolt P, Maak A, Wicklein EM, Thiele H, Altmuller J, Wagner F, Vinuela A, Aguirre LA, Moreno F, Maier H, Rau I, Giesselmann S, Nurnberg G, Gal A, Nurnberg P, Hubner CA, del Castillo I, Kurth I: Nonsense mutations in SMPX, encoding a protein responsive to physical force, result in X-chromosomal hearing loss. Am J Hum Genet 2011, 88:621-627.

33. Scully $J$ L: Disability and genetics in the era of genomic medicine. Nat Rev Genet 2008, 9:797-802

34. Christiansen JB: Sociological implications of hearing loss. Ann NY Acad Sci 1991, 630:230-235.

35. Grundfast KM, Rosen J: Ethical and cultural considerations in research on hereditary deafness. Otolaryngol Clin North Am 1992, 25:973-978

36. Stern SJ, Arnos KS, Murrelle L, Welch KO, Nance WE, Pandya A: Attitudes of deaf and hard of hearing subjects towards genetic testing and prenatal diagnosis of hearing loss. J Med Genet 2002, 39:449-453.

37. Dagan O, Hochner H, Levi H, Raas-Rothschild A, Sagi M: Genetic testing for hearing loss: different motivations for the same outcome. Am J Med Genet 2002, 113:137-143

38. Bunnik EM, Schermer MH, Janssens AC: Personal genome testing: test characteristics to clarify the discourse on ethical, legal and societal issues. BMC Med Ethics 2011, 12:11

39. Kaye J, Heeney C, Hawkins N, de Vries J, Boddington P: Data sharing in genomics - re-shaping scientific practice. Nat Rev Genet 2009, 10:331-335.

40. Pierce SB, Walsh T, Chisholm KM, Lee MK, Thornton AM, Fiumara A, Opitz JM, 
Levy-Lahad E, Klevit RE, King MC: Mutations in the DBP-deficiency protein HSD17B4 cause ovarian dysgenesis, hearing loss, and ataxia of Perrault Syndrome. Am J Hum Genet 2010, 87:282-288.

41. Sirmaci A, Walsh T, Akay H, Spiliopoulos M, Sakalar YB, HasanefendiogluBayrak A, Duman D, Farooq A, King MC, Tekin M: MASP1 mutations in patients with facial, umbilical, coccygeal, and auditory findings of Carnevale, Malpuech, OSA, and Michels syndromes. Am J Hum Genet 2010, 87:679-686

42. Zheng J, Miller KK, Yang T, Hildebrand MS, Shearer AE, DeLuca AP, Scheetz TE, Drummond J, Scherer SE, Legan PK, Goodyear RJ, Richardson GP, Cheatham MA, Smith RJ, Dallos P: Carcinoembryonic antigen-related cell adhesion molecule 16 interacts with a-tectorin and is mutated in autosomal dominant hearing loss (DFNA4). Proc Natl Acad SciU SA 2011, 108:4218-4223

43. Pierce SB, Chisholm KM, Lynch ED, Lee MK, Walsh T, Opitz JM, Li W, Klevit RE, King MC: Mutations in mitochondrial histidyl tRNA synthetase HARS2 cause ovarian dysgenesis and sensorineural hearing loss of Perrault syndrome. Proc Natl Acad Sci U S A 2011, 108:6543-6548.

44. Klein CJ, Botuyan MV, Wu Y, Ward CJ, Nicholson GA, Hammans S, Hojo K, Yamanishi H, Karpf AR, Wallace DC, Simon M, Lander C, Boardman LA, Cunningham JM, Smith GE, Litchy WJ, Boes B, Atkinson EJ, Middha S, PJ BD, Parisi JE, Mer G, Smith DI, Dyck PJ: Mutations in DNMT1 cause hereditary sensory neuropathy with dementia and hearing loss. Nat Genet 2011, 43:595-600.

45. Calvo SE, Compton AG, Hershman SG, Lim SC, Lieber DS, Tucker EJ, Laskowski A, Garone C, Liu S, Jaffe DB, Christodoulou J, Fletcher JM, Bruno DL, Goldblatt J, Dimauro S, Thorburn DR, Mootha VK: Molecular diagnosis of infantile mitochondrial disease with targeted next-generation sequencing. SciTransl Med 2012, 4:118ra10.

46. Winkelmann J, Lin L, Schormair B, Kornum BR, Faraco J, Plazzi G, Melberg A, Cornelio F, Urban AE, Pizza F, Poli F, Grubert F, Wieland T, Graf E, Hallmayer J,
Strom TM, Mignot E: Mutations in DNMT1 cause autosomal dominant cerebellar ataxia, deafness and narcolepsy. Hum Mol Genet 2012, 21:2205-2210

47. Dror AA and Avraham KB: Hearing impairment: a panoply of genes and functions. Neuron 2010, 68:293-308.

48. 1000 Genomes [http://www.1000genomes.org/home]

49. NCBI dbSNP [http://www.ncbi.n/m.nih.gov/projects/SNP/]

50. NHLBI Exome Sequencing Project [http://evs.gs.washington.edu/EVS/]

51. UCSC - Genome Bioinformatics [http://genome.ucsc.edu]

52. PolyPhen-2 [http://genetics.bwh.harvard.edu/pph2/]

53. SIFT Human Protein [http://sift.jcvi.org/www/SIFT_enst_submit.html]

54. The ConSurf Server [http://consurf.tau.ac.il/]

55. Sanger F, Nicklen S, Coulson AR: DNA sequencing with chain-terminating inhibitors. Proc Natl Acad Sci U S A 1977, 74:5463-5467.

56. Bartlett JM, Stirling D: A short history of the polymerase chain reaction. Methods Mol Biol 2003, 226:3-6.

57. Lander ES, Linton LM, Birren B, Nusbaum C, Zody MC, Baldwin J, Devon K, Dewar K, Doyle M, FitzHugh W, Funke R, Gage D, Harris K, Heaford A, Howland J, Kann L, Lehoczky J, LeVine R, McEwan P, McKernan K, Meldrim J, Mesirov JP, Miranda C, Morris W, Naylor J, Raymond C, Rosetti M, Santos R, Sheridan A, Sougnez C, et al:: Initial sequencing and analysis of the human genome. Nature 2001, 409:860-921

58. Shearer AE, Hildebrand MS, Sloan CM, Smith RJ: Deafness in the genomics era. Hear Res 2011. 282:1-9.

doi:10.1186/gb-2012-13-5-245

Cite this article as: Brownstein Z, et al.: High-throughput sequencing to decipher the genetic heterogeneity of deafness. Genome Biology 2012,

$13: 245$ 